Rechtsmedizin 2022 · 32:264-270 https://doi.org/10.1007/s00194-021-00536-y Accepted: 26 August 2021 Published online: 19 October 2021

(c) The Author(s) 2021

\section{Post-mortem computed tomography is a useful tool for determining the pulmonary ventilation status in newborns}

\author{
Florian T. Fischer' · Michael Schwerer · Stefanie Lochner' - Daniel Maxien² \\ Fabian Mück ${ }^{2}$ Laura Bechstein ${ }^{1} \cdot$ Stefan Wirth ${ }^{2}$. Jochen Grimm ${ }^{2,34}$ \\ ${ }^{1}$ Institute for Forensic Medicine, Ludwig-Maximilians-University, Munich, Germany \\ ${ }^{2}$ Institute for Clinical Radiology, Hospital of the Ludwig-Maximilians-University, Munich, Germany \\ ${ }^{3}$ Department of Medical Radiology, University Hospital Center and University of Lausanne, Lausanne, \\ Switzerland \\ ${ }^{4}$ Department of Forensic Imaging, University Center of Legal Medicine and University of Lausanne, \\ Lausanne, Switzerland
}

\title{
Abstract
}

Introduction: Lung ventilation is a standard sign of life in newborns. Post-mortem computed tomography (PMCT) is highly sensitive to the presence of gas in the body including the lungs. Current standard examinations to determine the pulmonary ventilation status in newborns are the flotation test and histology. The purpose of this study was to compare the accuracy of PMCT with the flotation test for determining the lung ventilation status with histological control as reference standard. A cut-off value as CT number in Hounsfield Units (HU) determining lung ventilation of newborns in PMCT should be established.

Methods: A total of 38 infant lungs were examined of which 21 lungs were from infants deceased shortly after live birth (control group) and 17 lungs belonged to infants where live birth was in question (study group). All lungs were examined using PMCT, flotation test, and histological examination.

Results: The control group showed an overall mean attenuation \pm standard deviation of $-219 \mathrm{HU} \pm 135$; the study group of $45 \pm 15 \mathrm{HU}$ in histologically nonventilated lungs versus $-192 \pm 207 \mathrm{HU} ;(p<0.001)$ in ventilated lungs. The best cut-off value for optimal discrimination of ventilated and nonventilated lungs in newborns was -35 mean HU.

\section{Infobox 1}

\section{Key points}

- Post-mortem computed tomography (PMCT) is equally well suited to determine lung ventilation as the flotation test. The best cut-off value for optimal discrimination of ventilated and nonventilated lungs in newborns was -35 mean $\mathrm{HU}$.

- Histology remains mandatory in ambiguous cases.

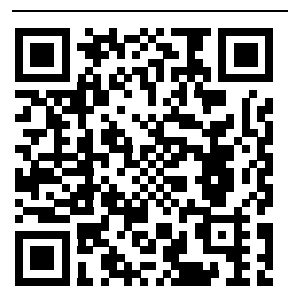

\section{Introduction}

Post-mortem computed tomography (PMCT) has been proven to be a useful tool for detecting gas and its distribution patterns $[1,2]$. It seems likely that the classical task of assessing the presence of air in the lungs of newborns by flotation tests [3-8] as a sign of life should be diagnosable by PMCT, because PMCT enables measuring Hounsfield units (HU) as a rough correlate of physical density, the same factor as examined with the flotation test. In recent studies, investigations including histology, macroscopic morphology and PMCT have been promoted. Few have been done so far but to our knowledge the number of cases examined in this manner and reported is still low $[9,10]$. Thus, it seemed neces- 

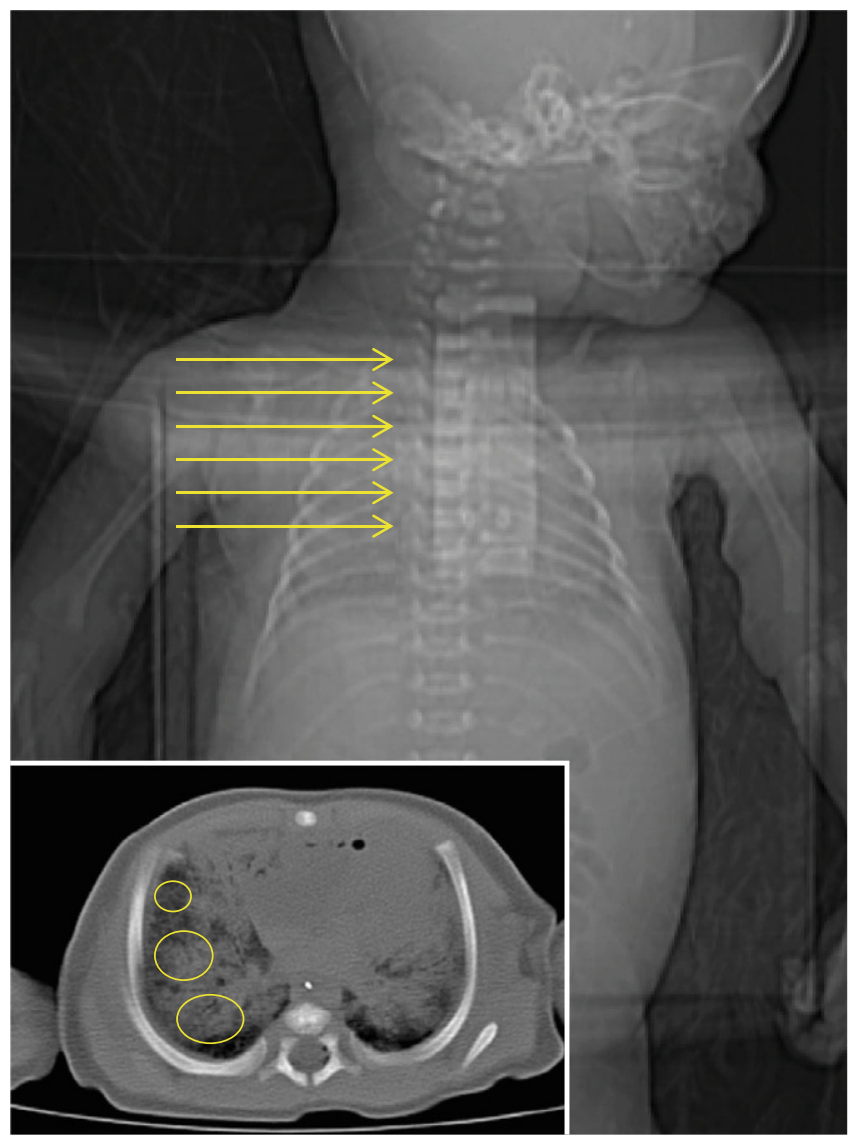

Fig. $1 \varangle$ Schematic of positioning of HU measurement ROIs (arrows: levels, ovals: ROI at each level). HU Hounsfield units, $R O /$ regions of interest

sary to establish further data suitable for statistical evaluation concerning PMCT in newborns, especially regarding the question of pulmonary ventilation. If suitable for this task, PMCT would enable a quick and efficient diagnosis of lung ventilation.

The purpose of this study was to determine if PMCT delivers at least comparably reliable results as the established lung flotation test and determine its correlation with histology.

\section{Material and methods}

\section{Study design}

For this retrospective study we defined a control group (group 2) to evaluate a "normal" range of $\mathrm{HU}$. The $\mathrm{HU}$ in the study group (group 1 with ventilated (1a) and nonventilated lungs (1b)) was compared with histology and the normal range of group 2 . were used for the examination and analysis.

\section{CT image acquisition}

The CT scans were performed on 64 row multidetector CT, a GE Discovery HD 750 (GE Healthcare $\mathrm{GmbH}$, Solingen, Germany) or a Philips Brilliance 64 (Philips $\mathrm{GmbH}$, Hamburg, Germany). Imaging parameters were $120 \mathrm{kV}$ and modulated tube current in helical mode with slice collimation of $0.625 \mathrm{~mm}$, with slice thickness of $2.5 \mathrm{~mm}$ after reconstruction. Images were reviewed on certified workstations, density measurements were done on the same equipment.

\section{CT image analysis}

A board-certified radiologist and a boardcertified forensic pathologist both with 5 or more years experience in post-mortem imaging analyzed all thoracic images and placed all regions of interest (ROls) in consensus. At the time of image analysis, the investigators were blinded with respect to autopsy and histology results. Measurements of attenuation values were performed on axial slices at the height of the center of the intervertebral discs of the thoracic vertebral column at levels of vertebrae $2 / 3,3 / 4,4 / 5,5 / 6,6 / 7$ and $7 / 8$. On each axial image 6 ovoid ROls of $0.3-0.9 \mathrm{~cm}^{2}$ were defined, 3 in the right and 3 in the left lung (anterior, central and posterior on both sides, - Fig. 1). Potential overlap with structures other than lung tissue (ribs, mediastinal structures, pleural air or fluid) was carefully avoided, as each ROI was optimized for maximum size. For each ROI, the mean attenuation value was recorded.

\section{Autopsy findings and flotation tests}

After image analysis the results of autopsy reports were analyzed in a systematic fashion. Autopsies were conducted according to German legislation. Specifically, the results of the floatation tests of the lungs were recorded. It was found to be positive if the lungs floated on the surface, holding neck organs when immersed in water, or the lungs separately, or parts of the lungs floated on the surface. In the 
Table 1 Demographics. Continuous variables are given as mean ( \pm standard deviation, SD), categorical variables are given as absolute number and percentage of the total

\begin{tabular}{|l|l|l|l|}
\hline \multirow{2}{*}{} & \multicolumn{2}{|l|}{ Group 1 } & Group 2 \\
\cline { 2 - 3 } & \multicolumn{2}{|l|}{ Subgroup 1a } & \multicolumn{2}{l|}{ Subgroup 1b } & \\
\hline Age at time of death & Perinatal & Perinatal & $7.9( \pm 3.1)$ weeks \\
\hline Sex & \multicolumn{1}{|l|}{10 male/7 female } & $\begin{array}{l}10 \text { male/11 fe- } \\
\text { male }\end{array}$ \\
\hline Height & $50.8( \pm 3.96) \mathrm{cm}$ & $57.4( \pm 2.73) \mathrm{cm}$ \\
\hline Weight & $3112( \pm 798) \mathrm{g}$ & $4578( \pm 1178) \mathrm{g}$ \\
\hline $\begin{array}{l}\text { Time interval between death and } \\
\text { PMCT }\end{array}$ & $<36 \mathrm{~h}$ & $<36 \mathrm{~h}$ & $<36 \mathrm{~h}$ \\
\hline & & Weight & Age \\
\hline Group 1 (neonates) & Height & $3112 \mathrm{~g}($ SD 823) & Perinatal death \\
\hline Group 2 (control) & $50.8 \mathrm{~cm}($ SD 4.08) & & 7.9 weeks (SD 3.1) \\
\hline
\end{tabular}

\section{Table 2 CT attenuation of examined ROIs}

\begin{tabular}{|l|l|l|l|l|l|}
\hline & $N$ & Minimum & Maximum & Mean & Std. Deviation \\
\hline Nonventilated (1a) & 313 & -50 & 72 & 45.25 & 15.617 \\
\hline Ventilated (1b) & 917 & -817 & 67 & -192.10 & 207.602 \\
\hline Control group (2) & 708 & -684 & 33 & -219.60 & 135.675 \\
\hline
\end{tabular}

control group, flotation tests were not performed because all children had breathed freely at some point after birth and no child in this group had lived less than $24 \mathrm{~h}$.

\section{Histology}

Histology provided the reference standard for the diagnosis of lung ventilation. All cases of the study and control groups were examined histologically. After fixation in buffered formalin solution and paraffin embedding routine serial sections were stained with hematoxylin and eosin staining (HE). A board-certified pathologist performed the histological examinations. Specimens were examined for aeration, packing of cells, aspiration, atelectasis, and infiltration.

\section{Statistical analysis}

Statistical analysis included the MannWhitney U-test for continuous variables as well as a receiver operating characteristic (ROC) analysis to determine the best $\mathrm{CT}$ attenuation cut-off value for the distinction of ventilated and nonventilated lungs.

Statistical analysis was performed using SPSS version16.0.1 for Windows (IBM, Armonk, NY, USA).

\section{Results}

\section{Study population}

The study population included 38 neonatal and infant cadavers (- Table 1) examined at the Institute of Forensic Medicine of the Ludwig Maximilians University Munich during the period from June 2008 to February 2012. The study group (group 1) comprised 17 infants with possible stillbirth and unclear cause of death.

The control group (group 2) consisted of the remaining 21 infants with certain live birth. Of these 21 infants the cause of death was determined as sudden infant death syndrome (SIDS) in 17 cases, battered child syndrome with blunt cerebral trauma in 2 cases, 1 case had suffered a cerebral sinus thrombosis and 1 had died from accidental strangulation.

\section{CT examination}

The median time interval between PMCT and autopsy was less than 1 day, ranging from $4 \mathrm{~h}$ to $24 \mathrm{~h}$. An interval greater than $36 \mathrm{~h}$ between death and PMCT was excluded. Typical examples with histology are displayed in 0 Figs. 2 and 3.

Of all examined ROls the overall mean $\mathrm{HU}$ in the histologically nonventilated study group (group 1a) was $45 \mathrm{HU}$ (SD $15 \mathrm{HU}$ ) versus $-192 \mathrm{HU}$ (SD $207 \mathrm{HU}$ ) in the ventilated study group (group 1b) whereas in the control group (group 2) mean CT attenuation was $-219 \mathrm{HU}$ (SD $135 \mathrm{HU}$ ) (ס Table 1). Differences of mean HU between groups $1 \mathrm{a}$ and 2 , and $1 \mathrm{a}$ and $1 \mathrm{~b}$ were statistically significant (both $p<0.001$ ), while no significant difference was found between groups $1 \mathrm{~b}$ and 2 . No statistically significant differences could be found between the anatomic regions, when comparing ventral with dorsal areas or cranial with caudal areas (- Table 2).

Mean $\mathrm{HU}$ values of all ROls are illustrated in histograms (- Fig. 4a-c). Note the similar distributions of $\mathrm{CT}$ attenuation values for ventilated lungs in study group and control group. While the shape of the distribution curve is similar in nonventilated specimens, the mean values differ strongly between ventilated and nonventilated lungs.

Mean and median densities of the nonventilated (1a) against ventilated study group (1b) showed a significantly different result $(p<0.05)$.

When comparing the control group (2) with the ventilated study group, no significant difference was found.

A receiver operating characteristic (ROC) analysis of the mean HU provided an optimal cut-off value of $-35 \mathrm{HU}$.

Using the mentioned cut-off value of $-35 \mathrm{HU}$ results in sensitivity, specificity, positive and negative predictive value, and accuracy of $86 \%, 90 \%, 86 \%, 90 \%$, and $88 \%$ respectively, for the discrimination of ventilated and nonventilated lungs in the study group.

\section{Flotation test and histology}

A negative test was interpreted as nonventilated lungs (stillborn), a positive test was interpreted as ventilated lungs (survived birth). In the study group a flotation test was done in all cases. It was found to be negative in 10 out of the 17 cases and positive in the remaining 7 cases; the result was confirmed by histology in 15 out of 17 cases. Those cases with unconfirmed result are discussed further.

In the control group, due to the fact that these infants had lived for at least 


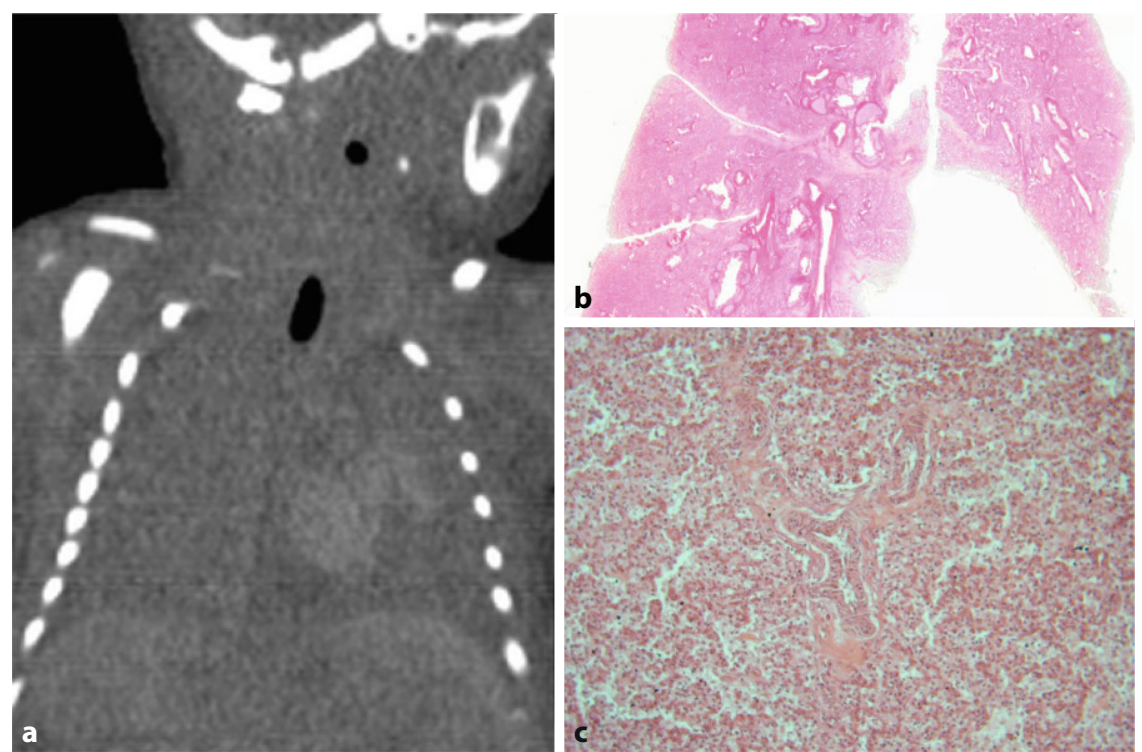

Fig. $2 \Delta$ a PMCT coronary view, nonventilated lung. b Histology nonventilated, regular anatomy, only aerated bronchi and bronchioli $(5 \times \mathrm{HE})$. c Histology nonventilated neonate, densely packed alveoli $(\times 200, \mathrm{HE})$
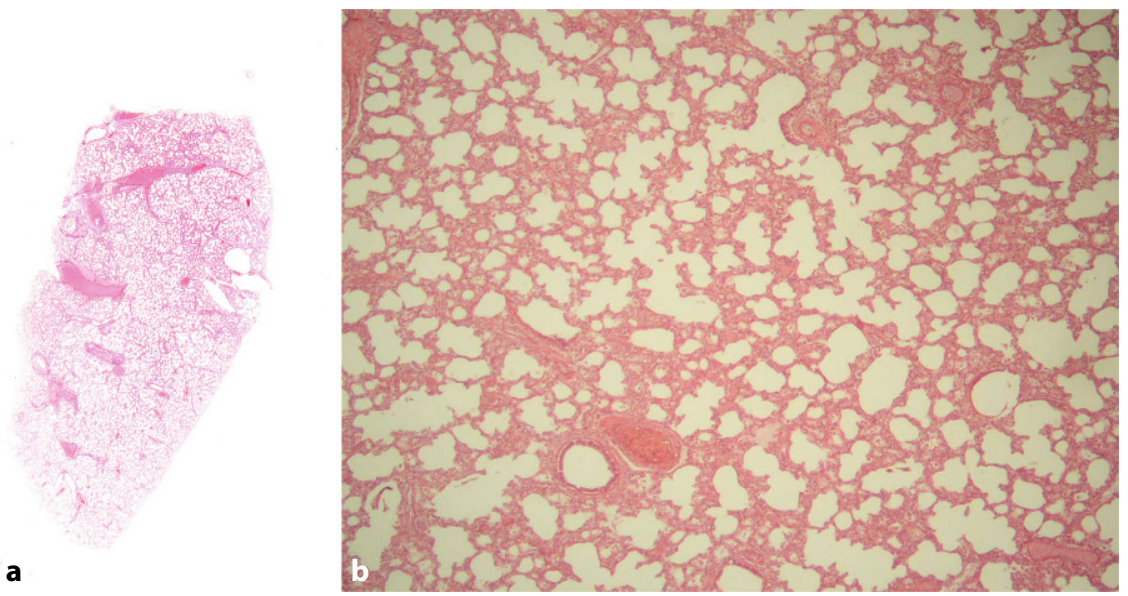

Fig. $3 \Delta$ a Histology regularly ventilated newborn lung, clearly aerated parenchyma $(\times 5, \mathrm{HE})$. b Histology detail of a, ventilated neonate, open aveolar spaces $(\times 100, \mathrm{HE})$

3 weeks, flotation tests were not applied during autopsy.

\section{Control group (group 2)}

The ventilated lungs of the control group showed uniform patterns of well-aerated and developed tissue: Dilated terminal bronchioli as well as open alveolar spaces intermingled with artificially collapsed tissue areas. Higher magnifications showed open alveolar spaces with a single, flattened cell layer on the alveolar septae.

\section{Study group (group 1)}

The cases in the study group that presented with high attenuation and nega-
Two cases of the study group showed a different pattern due to acute infection and putrefaction, respectively. They explain the singular false negative and false positive results. In these cases, histology was essential to determine the correct diagnosis. One of these cases showed a negative flotation test and a mean attenuation of $46.1 \mathrm{HU}$ (SD 5.3 HU); histology revealed acute pneumonia. The second case showed a partially positive lung flotation, with a mean attenuation of $22.1 \mathrm{HU}$ (SD $32.1 \mathrm{HU}$ ); histology revealed that the alveoli were still densely packed, immature cartilage prevailed the overall picture, detritus and fluids combined with a bubbly appearance, so the diagnosis of an unventilated but putrefied lung was established.

\section{Discussion}

The ventilation status of newborn lungs has been a constant topic in forensic medicine. From the very early conceptions of flotation tests by Johannes Schreyer in 1690 [9] to recent studies utilizing imaging techniques, mainly CT [9-13], proving that a newborn has been alive is mainly based on these findings, with histology as gold standard in ambiguous cases. The flotation test has been discussed extensively $[3,4,14]$, its use criticized but maintained until today. It is known to deliver unreliable results in cases of putrefaction or infections. Our results indicate that the attenuation value of PMCT with the appropriate cut-off value is equally well suited, but with the same shortcomings as the flotation test to determine lung ventilation.

These numbers might add to a basis of forensic radiological knowledge that is necessary to interpret post-mortem $\mathrm{CT}$. It seems obvious that ventilated lungs should show lower attenuation; however, our study was sufficiently large to support this hypothesis with statistical significance. Based on these results and our experience we believe that our cut-off values allow for a sufficiently reliable distinction between ventilated and nonventilated lungs within forensic requirements. The calculated optimal cut-off value is remarkably high when compared to regular lung parenchyma, but therefore should also include aerated lungs with moderate infiltrations. 


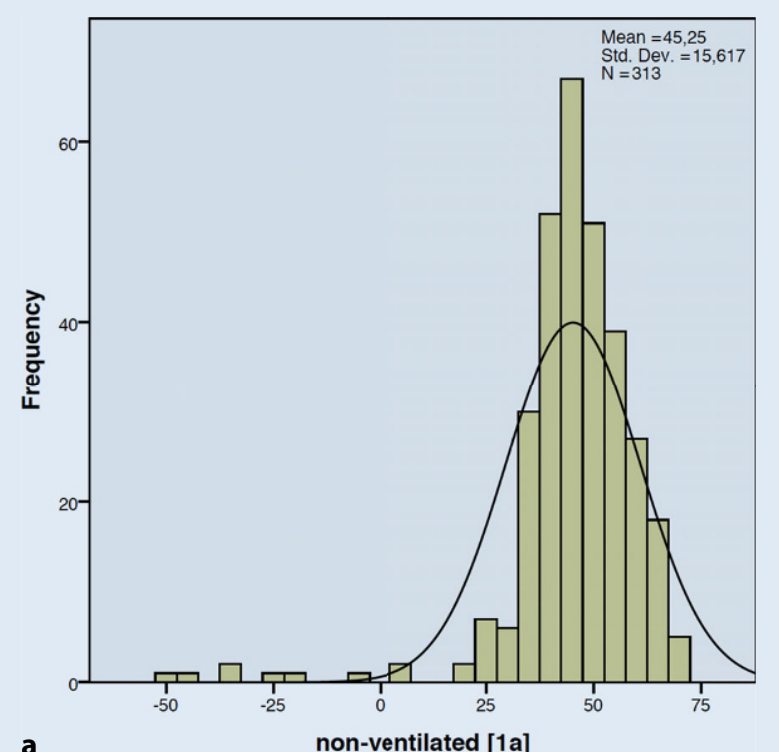

a

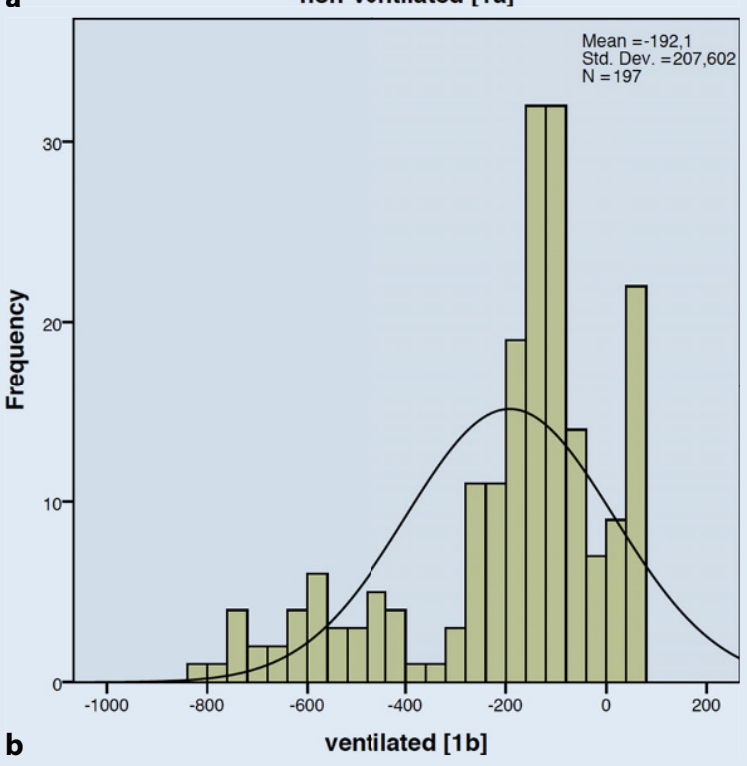

b

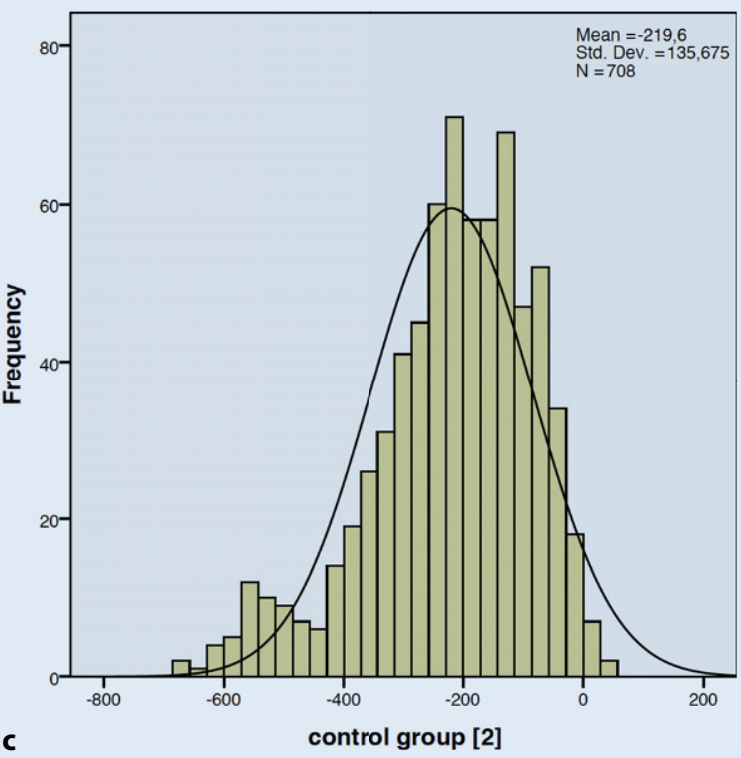

The histograms of the mean $\mathrm{HU}$ distributions illustrate well how accurate the discrimination is.

Unfortunately, the study design is not able to discriminate artificially ventilated lungs from lungs of children having actively breathed, but the same is true for the flotation test.

In addition to the results of previous studies, our results suggest a useful cut-off value for mean pulmonary $\mathrm{CT}$ attenuation of $-35 \mathrm{HU}$. Using this cut-off value, PMCT can be expected to accurately mirror results of a floatation test and to correctly determine the ventilation status of infant lungs in the vast majority of cases. It might be interesting to evaluate the amount of gas in the gastrointestinal tract to differentiate between natural breathing and ventilation in intubated patients. When we compared only neonates, we found relatively high values for sensitivity, specificity, positive and negative predictive values, and accuracy, concurring with forensic requirements, to be confirmed with histology in ambiguous cases.

Errors can occur especially in cases of live birth with pulmonary infiltration (e.g. pneumonia, pulmonary edema), or stillbirth with either advanced putrefaction or external ventilation, because these changes affect the measurable pulmonary attenuation; however, the flotation test is subject to the same errors for the same reasons. The $\mathrm{CT}$ in these cases is at this point not suitable to replace a histological examination, but it should render the flotation test unnecessary. Considering that every deceased infant or newborn should ideally undergo a PMCT screening for traumatic injury, the CT-based lung ventilation status would be a useful byproduct, and a flotation test would not be necessary anymore.

Isolated putrefaction of lungs would be
Fig. $4<$ a Histogram HU ROI nonventilated neonates (group 1b), b Histogram $\mathrm{HU}$ ventilated neonates (group 1a). c Histogram HU ventilated controls (group 2) (x-axis: HU, $y$ axis: Frequency). HU Hounsfield units, $R O /$ regions of interest a rare finding [4], which reflects routine autopsy experience. If it occurs, aspiration, e.g. of stomach contents, has to be considered, which may be diagnosed on PMCT by an experienced reader. PMCT examinations can establish a distribution pattern of gas, which can be used to stage putrefaction [2]. Application of the radiological alteration index (RAl) might be a way to optimize the reliability of a PMCT-based lung ventilation status. We did not cal- 
culate the RAl, because it is currently not evaluated for children, this might be an interesting topic of future research.

On the other hand, lung infiltration patterns on PMCT often hint at their pathological cause if interpreted by an experienced reader. Thus, PMCT can help to identify ambiguous cases and to determine if further histological evaluation is necessary or not.

In addition to evaluating lung ventilation and its reliability, PMCT offers various other advantages. The changes inflicted to bodies by resuscitation efforts very often result in a gas-distended stomach or pneumothorax, because of the mainly used initial approach of bag-mask ventilation. CT easily evaluates this due to its sensitivity to the presence of even small amounts of gas. Furthermore, in contrast to the flotation test, PMCT can be re-evaluated at any time after the initial interpretation, if necessary. Logistically, if PMCT is performed for its other advantages, an additional flotation test is unnecessary.

In comparison with post-mortem magnetic resonance imaging (MRI), CT seems better suited for evaluation of the ventilation status of newborn lungs for a number of reasons $[13,15,16]$. Firstly, CT is more widely available, cheaper, easier to interpret and the examination time is shorter. Secondly, its physical principle is closer to the flotation test, as the attenuation value is related to the physical density of an object and thus better reflects the rationale behind the flotation test, which also very simply measures lung density compared to water. The MRI on the other hand only measures signal intensity, which is not correlated with physical density and shows a dependence on temperature [17]. Also, MRI can be expected to be less precise for determining the presence of gas, because various conditions can exhibit low signal intensity, e.g. calcifications such as gas are hypointense on all sequences and can thus easily be confounded.

This study has some limitations.

Firstly, a control group of stillborn infants was not included, because these are very rarely examined for ethical reasons and if they are, the examination generally takes place in the department of clinical pathology, access was therefore limited. The inclusion of a control group of stillborn infants was considered less important, because we expected a relatively uniform attenuation distribution for ventilated lungs compared to a less homogeneous distribution of attenuation in nonventilated lungs. Furthermore, the difference in attenuation between ventilated and nonventilated lungs was expected to be high, so that a control group of one of the two states of ventilation was considered sufficient. Also, and most importantly, histological evaluation was used as reference to clearly diagnose ambiguous cases. Because of using the histological examination as ground truth, all cases examined could be used to determine a cutoff value for lung attenuation to distinguish ventilated from nonventilated lungs and the total case number for both ventilated and nonventilated lungs was sufficient for statistical evaluation.

Secondly, the examined group of infants is still small. Nonetheless, it is to our knowledge larger than any other case group published in this context. It also allows for statistical evaluation and therefore is less likely to be biased than previous studies.

Thirdly, since the control group (group 2) was chosen retrospectively, we could not perform a floatation test on these. Since all infants in the control group had lived well beyond birth and at least at some point after birth had breathed freely as proof of lung ventilation, we considered a flotation test unnecessary.

\section{Conclusion}

Lung attenuation values from PMCT allow for a reliable distinction between ventilated and nonventilated lungs using a cutoff value of $-35 \mathrm{HU}$ in newborns.

Using this cut-off value, PMCT and flotation test deliver identical results for diagnosing lung ventilation with a sensitivity of $86 \%$ and a specificity of $90 \%$. When PMCT is performed in infants, an additional flotation test can be considered unnecessary. In ambiguous cases, PMCT and flotation test both need to be complemented with histological work-up.

\section{Corresponding address}

\section{Florian T. Fischer}

Institute for Forensic Medicine, Ludwig-

Maximilians-University

Nußbaumstr. 26, 80336 Munich, Germany

florian.fischer@med.uni-muenchen.de

Funding. Open Access funding enabled and organized by Projekt DEAL.

\section{Declarations}

Conflict of interest. F. T. Fischer, M. Schwerer, S. Lochner, D. Maxien, F. Mück, L. Bechstein, S. Wirth and J. Grimm declare that they have no competing interests.

All investigations on humans or human tissues described in this article were carried out with the approval of the responsible ethics committee, in accordance with national law and the Declaration of Helsinki from 1975 (in its current revised form). The investigations were carried out according to the specifications of the Central Ethics Committee of the Federal Medical Council.

Open Access. This article is licensed under a Creative Commons Attribution 4.0 International License, which permits use, sharing, adaptation, distribution and reproduction in any medium or format, as long as you give appropriate credit to the original author(s) and the source, provide a link to the Creative Commons licence, and indicate if changes were made. The images or other third party material in this article are included in the article's Creative Commons licence, unless indicated otherwise in a credit line to the material. If material is not included in the article's Creative Commons licence and your intended use is not permitted by statutory regulation or exceeds the permitted use, you will need to obtain permission directly from the copyright holder. To view a copy of this licence, visit http://creativecommons.org/licenses/by/4.0/.

\section{References}

1. Michiue $T$, Ishikawa $T$, Oritani $S$, Kamikodai $Y_{,}$ Tsuda K, Okazaki S, Maeda H (2013) Forensic pathological evaluation of postmortem pulmonary $\mathrm{CT}$ high-density areas in serial autopsy cases of sudden cardiac death. Forensic Sci Int 232(1-3):199-205. https://doi.org/10.1016/j. forsciint.2013.07.025

2. Egger C, Vaucher P, Doenz F, Palmiere C, Mangin P, Grabherr S (2012) Development and validation of a postmortem radiological alteration index. the RA-index. Int J Legal Med 126(4):559-566. https:// doi.org/10.1007/s00414-012-0686-6

3. Buris L, Töröcsik I, Poczkodi S (1979) Is the aeration of the lungs a reliable sign of live birth? Z Rechtsmed 83(4):303-312. https://doi.org/10. 1007/BF01882176

4. Haberda A (1902) Zur Frage des Beweiswerthes der Lungenprobe. Arch Gynak 67(1):276-290. https:// doi.org/10.1007/BF01950913

5. Nolte G (1938) Untersuchungen über die Bedeutung des Röntgenbildes als Lebensprobe in der 
gerichtlich-medizinischen Praxis. Dtsch Z ges gerichtl Med 30(2-3):116-126. https://doi.org/10. 1007/BF01754200

6. Ungar E (1891) Die Bedeutung der Lebensproben und im Speciellen der Magendarmprobe. Archiv $f$ pathol Anat 125(1):1-24. https://doi.org/10.1007/ BF01970292

7. Brittain RP (1963) The hydrostatic and similar tests of live birth: a historical review. Med Leg J 31:189-194. https://doi.org/10.1177/ 002581726303100404

8. Grosse Ostendorf AL, Rothschild MA, Muller AM, Banaschak S (2013) Is the lung floating test a valuable tool or obsolete? A prospective autopsy study. Int J Legal Med 127(2):447-451. https://doi org/10.1007/s00414-012-0727-1

9. Oyake $Y$, Aoki T, Shiotani S, Kohno M, Ohashi N, Akutsu H, Yamazaki K (2006) Postmortem computed tomography for detecting causes of sudden death in infants and children. retrospective review of cases. Radiat Med 24(7):493-502. https://doi. org/10.1007/s11604-006-0061-y

10. Michiue $T$, Ishikawa $T$, Kawamoto O, Sogawa $N$, Oritani S, Maeda H (2013) Postmortem CT investigation of air/gas distribution in the lungs and gastrointestinal tracts of newborn infants. a serial case study with regard to still-and live birth Forensic Sci Int 226(1-3):74-80. https://doi.org/ 10.1016/j.forsciint.2012.12.011

11. Arthurs OJ, Hutchinson JC, Sebire NJ (2017) Current issues in postmortem imaging of perinatal and forensic childhood deaths. Forensic Sci Med Pathol 13(1):58-66. https://doi.org/10.1007/s12024016-9821-x

12. Guddat SS, Gapert R, Tsokos M, Oesterhelweg L (2013) Proof of live birth using postmortem multislice computed tomography (pmMSCT) in cases of suspected neonaticide. advantages of diagnostic imaging compared to conventional autopsy. Forensic Sci Med Pathol 9(1):3-12. https://doi.org/10.1007/s12024-012-9361-y

13. Barber JL, SebireNJ, Chitty LS, Taylor AM, Arthurs OJ (2015) Lung aeration on post-mortem magnetic resonance imaging is a useful marker of live birth versus stillbirth. Int J Legal Med 129(3):531-536. https://doi.org/10.1007/s00414-014-1125-7

14. Hitschmann F, Lindenthal $O$ (1902) Zur Frage der Verwerthbarkeit der Lungenschwimmprobe bei Keimgehalt der Uterushöhle. Arch Gynak 66(2):350-364. https://doi.org/10.1007/ BF01671646

15. Michiue T, Ishikawa T, Kawamoto O, Sogawa N, Oritani S, Maeda H (2013) Postmortem CT investigation of air/gas distribution in the lungs and gastrointestinal tracts of newborn infants. a serial case study with regard to still-and live birth. Forensic Sci Int 226(1-3):74-80. https://doi.org/ 10.1016/j.forsciint.2012.12.011

16. Sogawa N, Michiue T, Ishikawa T, Kawamoto 0 , Oritani S, Maeda H (2014) Postmortem volumetric CT data analysis of pulmonary air/gas content with regard to the cause of death for investigating terminal respiratory function in forensic autopsy. Forensic Sci Int 241:112-117. https://doi.org/10. 1016/j.forsciint.2014.05.012

17. Ruder TD, Hatch GM, Siegenthaler L, Ampanozi G, Mathier S, Thali MJ, Weber OM (2012) The influence of body temperature on image contrast in post mortem MRI. Eur J Radiol 81(6):1366-1370. https://doi.org/10.1016/j.ejrad.2011.02.062

\section{Postmortale Computertomographie als Instrument zum Belüftungsnachweis bei Neugeborenen}

Einleitung: Die Belüftung der Lungen gilt als vitales Zeichen bei Neugeborenen. Computertomographische (CT) Untersuchungen sind hochsensitiv für den Nachweis von Gasen im Körper, einschließlich der Lungen. Aktuelle Standarduntersuchungen zur Beurteilung der Lungenbelüftung bei Neugeborenen sind Schwimmprobe und Histologie. Ziel dieser Studie war ein Vergleich der Genauigkeit von postmortaler CT (PMCT) und Schwimmprobe zur Beurteilung der Lungenbelüftung mit histologischer Kontrolle als Referenzstandard. Ein Cut-off-Wert der CT-Dichte in Hounsfield-Einheiten (HE) für Lungenbelüftung im PMCT bei Neugeborenen sollte etabliert werden. Methoden: Insgesamt wurden 38 kindliche Lungen untersucht, von denen 21 kurz nach der Lebendgeburt verstorben waren (Kontrollgruppe) und 17 mit der Fragestellung einer Totgeburt zur Sektion kamen (Studiengruppe). Alle Lungen wurden mittels PMCT, Schwimmprobe und Histologie untersucht.

Ergebnisse: In der CT zeigte die Kontrollgruppe im Mittel \pm Standardabweichung eine Lungenparenchymdichte von $-219 \pm 135 \mathrm{HE}$; die Studiengruppe von $45 \pm 15 \mathrm{HE}$ in den histologisch nicht ventilierten Lungen gegenüber $-192 \pm 207 \mathrm{HE} ;(p<0,001)$ in den ventilierten reifen Lungen. Als bester Cut-off Wert zur Unterscheidung des Ventilationsstatus wurden $-35 \mathrm{HE}$ ermittelt.

Schlussfolgerung: Die PMCT ist der Lungenschwimmprobe zur Beurteilung des pulmonalen Ventilationsstatus gleichwertig. Gleichzeitig können damit wertvolle Zusatzbefunde zu Infiltraten, Fäulnisgrad und möglichen Traumafolgen (Frakturen, Pneumothorax) erhoben werden. Die histologische Untersuchung bleibt vor allem in Zweifelsfällen unverzichtbar.

\section{Schlüsselwörter}

Ventilation · Forensische Radiologie · Lebendgeburt · Totgeburt · Schwimmprobe 